\title{
PENGARUH KEPEMIMPINAN TRANSFORMASIONAL DAN KEPUASAN KERJA TERHADAP ORGANIZATIONAL CITIZENSHIP BEHAVIOUR PADA PT. PLN RAYON BELANTI PADANG
}

\author{
Sepri Gunadi, Aminar Sutra Dewi \\ Sekolah Tinggi Ilmu Ekonomi KBP \\ seprigunadi6@gmail.com
}

\begin{abstract}
Organizational Citizenship Behavior can improve interpersonal skills in PT.Pln Rayon Belanti employees.The purpose of this study was to determine the effect of transformational leadership and job satisfaction on organizational citizenship behavior on PT.PLN Rayon Belanti.This study used primary data obtained from interviews and questionnaires distribution with total sampling technique to 42 employees of PT PLN Rayon Belanti. Data analysis in this study using multiple linear regression technique.The results showed that transformational leadership had positive and significant effect on organizational citizenship behavior. Job satisfaction has a positive and significant effect on the organizational citizen ship behavior.
\end{abstract}

Keywords: transformational leadership, work satisfaction, organizational citizenship behavoiur

\section{PENDAHULUAN}

Menurut Organ et al. (2006:8) dalam (Rahmi, 2013) mendefinisikan OCB sebagai perilaku individual yang bersifat bebas, dan tidak secara langsung mendapat penghargaan dari sistem imbalan formal, tetapi secara keseluruhan dapat meningkatkan efisiensi dan efektifitas fungsifungsi organisasi.PT PLN Rayon Belanti adalah sebuah BUMN yang mengurusi semua aspek kelistrikan yang ada di Padang yang mengurusi Pembangkitan, Penyaluran (Transmisi) dan Pengaturan Beban, dan Distribusi kepada pelanggan. Berdasarkan dari hasil wawancara yang telah dilakukan benar adanya bahwa beberapa karyawan PT PLN Rayon Belanti menampilkan Organizational Citizenship Behaviour, contohnya seorang karyawan yang menjabat sebagai pemelihara distribusi yang diskripsi pakerjannya melakukan injeksi lapangan yang artinya dia harus mencek langsung kelapangan bagaimana jaringan listrik pelanggan dan jika ada kejanggalan disinilah dia harus memperbaiki jaringan listrik tersebut, tidak hanya itu karyawan yang peneliti temui juga menceritakan bahwa dia juga sering membantu temannya yang bekerja di bagian gudang jika semua pekerjaanya telah selesai padahal tidak ada tambahan gaji/upah untuk ini. Berbeda lagi dengan yang peneliti temui pada saat wawancara dengan salah satu karyawan di PT PLN Rayon Belanti, salah satu dari mereka menyatakan bahwa terkadang sebelum jam bekerja usai, mereka telah 
dahulu pulang kerumah dikarenakan tidak ada pekerjaan atau pekerjaan tersebut masih bisa dilakukan esok hari tanpa sepengetahuan atasan.Sesuai dengan judul yang diangkat yaitu pengaruh kepemimpinan transformasional dan kepuasan kerja terhadap organizational citizenship behaviour pada PT PLN Rayon Belanti serta dihubungkan dengan hasil wawancara maka terdapat masalah yang menghambat munculnya organizational citizenship behaviour yaitu masih terdapat beberapa karyawan yang menunda waktu dalam melaksanakan tugasnya, ini sangat mengganggu tujuan yang akan dicapai oleh PT PLN Rayon Belanti.

Antonakis et al. (2003)dalam (Rahmi, 2013) mendefinisikan kepemimpinan transformasional sebagai sebuah perilaku yang bersifat proaktif, meningkatkan perhatian atas kepentingan bersama, dan membantu para pengikut mencapai tujuan pada tingkatan yang paling tinggi. Pemimpinan transformasional adalah pemimpin yang mendorong para pengikutnya untuk merubah motif, kepercayaaan, nilai, dan kemampuan sehingga minat dan tujuan pribadi dari para pengikut dapat selaras dengan visi dan tujuan organisasi (Goodwin et al., 2001)dalam (Rahmi, 2013).Karyawan PT PLN Rayon Belanti merasa memiliki pemimpin yang memperhatikan karyawannya, karyawan bebas berpendapat demi kebaikan PT PLN Rayon Belanti, pemimpinnya tidak semena mena dalam bertindak apalagi tidak menjalankan Standar Operasi Kerja (SOP) yang seharusnya. Pemimpin yang seperti inilah yang diharapkan menjadi pemimpin untuk semua perusahaan demi kelangsungan kehidupan perusahaan dan mensejahterakan karyawan sehingga nantinya tidak hanya karyawan yang puas akan pekerjaannya tetapi juga pelanggan.Namun dari hasil wawancara penulis menemui bahwa pemimpin di PT PLN Rayon Belanti dinilai kurang tegas kepada karyawannya dikarenakan masih adanya perasaan tidak enak atau segan antar pemimpin dengan bawahan dikarenakan pautan umur yang tidak jauh berbeda.

Tidak hanya kepemimpinan transformasional, kepuasan kerja juga memengaruhi munculnya organizational citizenship behaviour.Luthans (2006) dalam (Baihaqi, 2010)berpendapat bahwa kepuasan kerja adalah perasaan pekerja atau karyawan yang berhubungan dengan pekerjaannya, yaitu merasa senang atau tidak senang, sebagai hasil penilaian individu yang bersangkutan terhadap pekerjaannya.

Dilihat dari segi sosial, karyawan di PT PLN Rayon Belanti merasa puas akan pekerjaan yang dilakukannya. Pekerjaan yang dilakukan dinilai sangat membantu masyarakat karena listrik merupakan penunjang kehidupan. Listrik adalah kebutuhan utama masyarakat, tanpa listrik roda ekonomi bisa macet total pasalnya banyak pabrik dan industri besar yang menggunakan listrik dan bergantung pada listrik. Dalam kehidupan sehari haripun masyarakat mengandalkan listrik, mulai dari memasak, belajar dan lainnya. Oleh sebab itu karyawan PT PLN Rayon Belanti menyimpulkan bahwa mareka puas atas pekerjaan yang dilakukannya karena bermanfaat untuk masyarakat. Lain halnya jika dilihat dari segi finansial, karyawan PT PLN Rayon Belanti merasa kurang puas akan gaji/upah yang diterima disebabkan hanya menerima sebatas upah minimum regional saja yang hanya bisa mencukupi untuk kehidupan sehari hari saja tanpa bonus dari perusahaan padahal pekerjaan yang dilakukan cukup berisiko.Pada penelitian kali ini penulis meneliti tentang pengaruh kepemimpinan transformasional dan 
kepuasan kerja terhadap organizational citizenship behaviour dengan memilih objek .

Pengembangan Hipotesis

1. Pengaruh Kepemimpinan Transformasional terhadap Organizational Citizenship Behaviour

Antonakis et al. (2003) dalam (Rahmi, 2013) mendefinisikan kepemimpinan transformasional sebagai sebuah perilaku yang bersifat proaktif, meningkatkan perhatian atas kepentingan bersama, dan membantu para pengikut mencapai tujuan pada tingkatan yang paling tinggi. Pemimpinan transformasional adalah pemimpin yang mendorong para pengikutnya untukmerubah motif, kepercayaaan, nilai, dan kemampuan sehingga minat dan tujuan pribadi dari para pengikut dapat selaras dengan visi dan tujuan organisasi (Goodwin et al., 2001) dalam(Rahmi, 2013) .Menurut Komalasari, dkk (2012) dalam (Psikologi et al., 2017) Organizational Citizenship Behaviour dapat didefinisikan sebagai karyawan/pegawai yang memberikan kontribusi terhadap berfungsinya organisasi secara efektif yang tidak secara eksplisit diminta.

Menurut Rahmi (2003) yang meneliti tentang pengaruh kepemimpinan transformasional terhadap organizational citizenship behaviour, menunjukkan bahwa kepemimpinan transformasional berpengaruh positif dan signifikan terhadap organizational citizenship behavior.Menurut Prabowo (2014) yang meneliti tentang analisis pengaruh kepemimpinan transformasional dan kepuasan kerja terhadap organizational citizenship behavior dengan menggunakan teknik regresi linier berganda menunjukkan bahwa kepemimpinan transformasional berpengaruh positif dan signifikan terhadap organizational citizenship behavior. Sama halnya dengan (Kaihatu, dkk 2007) yang meneliti tentang kepemimpinan transformasional dan pengaruhnya terhadap kepuasan atas kualitas kehidupan kerja, komitmen organisasi, dan perilaku ekstra peran (OCB) menunjukkan hasilbahwa kepemimpinan transformasional berpengaruh positif dan signifikan terhadap organizational citizenship behavior.

$\mathrm{H}_{1}$ :Diduga kepemimpinan transformasional berpengaruh positif dan signifikan terhadap organizational citizenship behavior.

2. Pengaruh Kepuasan Kerja terhadap Organizational Citizenship Behaviour

Kepuasan kerja merupakan hal yang bersifat individual. Setiap individu mempunyai tingkat kepuasan yang berbeda-beda, seperti yang didefinisikan oleh Kreitner dan Kinicki (2005), bahwa kepuasan kerja sebagai efektivitas atau respons emosional terhadap berbagai aspek pekerjaan. Definisi ini mengandung pengertian bahwa kepuasan kerja bukanlah suatu konsep tunggal, sebaliknya seseorang dapat relatif puas dengan suatu aspek dari pekerjaannya dan tidak puas dengan salah satu atau beberapa aspek lainnya.Menurut Komalasari, dkk (2012) Organizational Citizenship Behaviour dapat didefinisikan sebagai karyawan/pegawai yang memberikan kontribusi terhadap berfungsinya organisasi secara efektif yang tidak secara eksplisit diminta.

Menurut Prabowo (2014) yang meneliti tentang analisis pengaruh kepemimpinan transformasional dan kepuasan kerja terhadap organizational citizenship behavior dengan menggunakan teknik regresi linier berganda menunjukkan bahwa kepuasan kerja berpengaruh positif dan signifikan terhadap 
organizational citizenship behavior. Menurut Otmo (2001) yang meneliti tentang pengaruh karakterisitik pekerjaan dan kepuasan kerja terhadap organizational citizenship behavior menunjukkan bahwa tidak terdapat pengaruh signifikan kepuasan kerja terhadap organizational citizenship behavior.

$\mathrm{H}_{2}$ :Diduga kepuasan kerja berpengaruh positif dan signifikan terhadap organizational citizenship behavior.

Maka hasil yang di ketahui adalah sebagai berikut:

H1:Diduga kepemimpinan transformasional berpengaruh positif dan signifikan terhadap organizational citizenship behavior.

H2:Diduga kepuasan kerja berpengaruh positif dan signifikan terhadap organizational citizenship behavior.

\section{METODE PENELITIAN}

Jenis penelitian ini adalah penelitian kuantitatif. Penelitian kuantitatif adalah data yang berbentuk angka yaitu untuk menganalisa pengaruh kepemimpinan transformasional dan kepuasan kerja terhadap organizational citizenship behaviourpada PT PLN Rayon Belanti.

Objek penelitian yaitu seluruh pegawan/karyawan PT.PLN Rayon Belanti.

Populasi adalah wilayah generalisasi yang terdiri atas objek atau subjek yang mempunyai kualitas dan karakteristik tertentu yang ditetapkan oleh peneliti untuk dipelajari, kemudian ditarik kesimpulannya (Sugiono, 2015)dalam(Baihaqi, 2010) . Jadi populasi merupakan objek atau subjek yang berada pada suatu wilayah dan memenuhi syarat syarat tertentu yang mempunyai kaitan dengan masalah yang diteliti. Populasi dalam penelitian ini adalah karyawan pada PT PLN Rayon Belanti yang berjumlah 42 orang (Sugiono, 2015) dalam(Baihaqi, 2010).

Sampel adalah sebagian dari jumlah populasi tersebut. Hadi (dalam Narbuko \& Ahmadi) menyatakan bahwa sampel adalah sebagian individu yang diselidiki dari keseluruhan individu penelitian. Teknik pengambilan sampel dalam penelitian ini adalah teknik total sampling, dimana seluruh populasi yang ada menjadi sampel penelitian. Arikunto (2002) ("No Title," n.d.)mengemukakan jika jumlah populasi kurang dari 100 oang maka penentuan jumlah sampel ditentukan secara total sampling. Maka jumlah sampel dalam penelitian ini adalah sebanyak 42 orang.

Sumber data Pada penelitian ini, data primer adalah data yang diperoleh secara langsung dari sumbernya, diamati, dan dicatat untuk pertama kalinya melalui wawancara atau hasil pengisian kuesioner kepada responden penelitian yang dijadikan sampel yaitu karyawan PT PLN Rayon Belanti.

Teknik pengumpulan data yang dipergunakan dalam penelitian ini adalah :

a. Kuesioner merupakan teknik pengumpulan data dengan cara memberi seperangkat pertanyaan atau pernyataan tertulis kepada responden untuk dijawabnya.

b. Observasi adalah pengamatan yang dilakukan secara langsung kepada suatu objek yang diteliti. Objek adalah karyawan PT PLN Rayon Belanti.

c.Wawancara adalah cara pengumpulan data dengan jalan tanya jawab sepihak yang dikerjakan secara sistematik dan berlandaskan tujuan penelitian. 


\section{Defenisi Operasional Variabel}

Tabel 1

Defenisi Operasional Variabel

\begin{tabular}{|c|c|c|c|c|}
\hline No & Variabel & Pengertian & Indikator & Skala \\
\hline 1. & $\begin{array}{l}\text { Organizational } \\
\text { Citizenship } \\
\text { Behaviour }(\mathrm{Y})\end{array}$ & 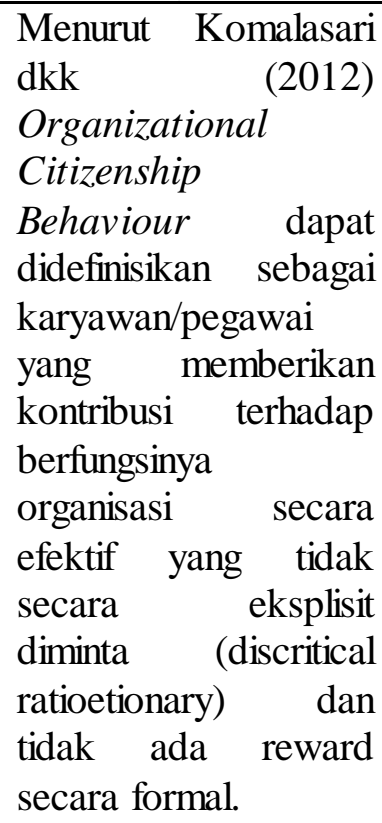 & $\begin{array}{l}\text { 1. Altruism Helping } \\
\text { 2. Conscientiousn } \\
\text { 3. Sportmanship } \\
\text { 4. Courtesy } \\
\text { Civic Virtue } \\
\text { (Menurut Organ } \\
\text { dan Ryan dalam } \\
\text { Greenberg dan } \\
\text { Baron 2003) }\end{array}$ & $\begin{array}{l}\text { SS (Sangat } \\
\text { Setuju) : } 5 \\
\text { S (Setuju) }: 4 \\
\text { N (Netral) }: 3 \\
\text { TS (Tidak } \\
\text { Setuju) : } 2 \\
\text { STS (Sangat } \\
\text { Tidak Setuju) } \\
: 1\end{array}$ \\
\hline 2. & $\begin{array}{l}\text { Kepemimpinan } \\
\text { Transformasional } \\
\left(\mathrm{X}_{1}\right)\end{array}$ & $\begin{array}{lr}\text { Antonakis et } & \text { al. } \\
(2003) & \\
\text { mendefinisikan } & \\
\text { kepemimpinan } & \\
\text { transformasional } & \\
\text { Sebagai } & \text { sebuah } \\
\text { perilaku } & \text { yang } \\
\text { bersifat proaktif, } \\
\text { meningkatkan } \\
\text { perhatian } \\
\text { kepentingan } \\
\text { bersama, atas } \\
\text { membantu } \\
\text { pengikut mencapai } \\
\text { tujuan } \\
\begin{array}{l}\text { tingkatan } \\
\text { paling tinggi }\end{array}\end{array}$ & $\begin{array}{l}\text { 1. Idealized } \\
\text { influence } \\
\text { (pengaruh ideal). } \\
\text { 2. Inspirational } \\
\text { motivation } \\
\text { (motivasi } \\
\text { inspirasi). } \\
\text { 3. Intellectual } \\
\text { stimulation } \\
\text { (stimulasi } \\
\text { intelektual). } \\
\text { 4. Individualized } \\
\text { consideration } \\
\text { (konsiderasi } \\
\text { individu). } \\
\text { (Menurut Bass dan } \\
\text { Avolio dalam } \\
\text { Swandari 2003) }\end{array}$ & $\begin{array}{l}\text { SS(Sangat } \\
\text { Setuju) : } 5 \\
\text { S(Setuju) : } 4 \\
\text { N(Netral) : } 3 \\
\text { TS(Tidak } \\
\text { Setuju) : } 2 \\
\text { S(Sangat } \\
\text { Tidak Setuju) } \\
: 1\end{array}$ \\
\hline
\end{tabular}




\begin{tabular}{|c|c|c|c|c|}
\hline & & & & \\
\hline 3. & $\begin{array}{l}\text { Kepuasan } \\
\operatorname{Kerja}\left(X_{2}\right)\end{array}$ & $\begin{array}{lr}\text { Menurut } & \text { Kreitner } \\
\text { dan Kinicki } & (2005), \\
\text { bahwa } & \text { kepuasan } \\
\text { kerja } & \text { sebagai } \\
\text { efektivitas } & \text { atau } \\
\text { respons } & \text { emosional } \\
\text { terhadap } & \text { berbagai } \\
\text { aspek pekerjaan. }\end{array}$ & $\begin{array}{l}\text { 1.Menyenangi } \\
\text { pekerjaannya } \\
\text { 2.Mencintai } \\
\text { pekerjaannya } \\
\text { 3.Moral kerja } \\
\text { 4. kedisiplinan } \\
\text { 5.Prestasi kerja } \\
\text { (Menurut Malayu } \\
\text { S.P Hasibuan } 2008 \\
\text { :202 ) }\end{array}$ & $\begin{array}{l}\text { SS(Sangat } \\
\text { Setuju) : } 5 \\
\text { S(Setuju) : } 4 \\
\text { N(Netral) : } 3 \\
\text { TS(Tidak } \\
\text { Setuju) : } 2 \\
\text { STS(Sangat } \\
\text { Tidak Setuju) } \\
: 1\end{array}$ \\
\hline
\end{tabular}

Teknik Analisa Data :

1. Uji validitas adalah suatu uji statistik yang digunakan untuk mengetahui apakah instrumen (angket/kuesioner) yang digunakan untuk mengambil data dalam penelitian yang digunakan layak atau tidak dipergunakan untuk pengambilan data yang selanjutnya digunakan untuk pengambilan keputusan daalm penelitian.Menurut Ghozali (2008)dalam (Baihaqi, 2010), untuk mengetahui apakah pertanyaan pertanyaan valid atau tidak, maka digunakan pearson correlation yaitu mengkorelasikan masing masing item pertanyaan terhadap total item pertanyaan, dan nilainya dapat di lihat pada hasil pengelolaan menggunakan program SPSS pada table item- total statistic di kolam corrected item di kolom total correlation.Validnya sebuah di tentukan dari nilai koefesien korelasi yang di hasilkan besar dari 0,30 dan dapat di gunakan untuk selanjutnya.

2. Uji Reliabilitas Secara umum didefinisikan sebagai rangkaian uji lanjutan untuk menilai kehandalan dari item -item pertanyaan yang valid yang di lihat dari nilai cronbach alpha yang di hasilkan >0,60 (Sugiono,2015). Suatu kuesioner, dapat dikatakan reliable atau handal jika jawaban seseorang terhadap pertanyaan adalah konsisten atau stabil dari waktu ke waktu.

Analisis Deskriptif untuk menggambarkan karakteristik masing-masing variabel penelitian. Analisa ini tidak menghubung-hubungkan satu variabel dengan variabel lainnya dan tidak membandingkan satu variabel dengan variabel lain. Untukmendapatkan rata-rata skor masing-masing indikator dan pertanyaanpertanyaan yang terdapat dalam kuesioner dipakai rumus berikut:

Rata-rata skor $=\underline{(5 . S S)+(4 . S)+(3 . N)+(2 . T S)+(1 . S T S)}$

$$
\mathrm{SS}+\mathrm{S}+\mathrm{N}+\mathrm{TS}+\mathrm{STS}
$$

Sedangkan mencari tingkat pencapaian jawaban responden digunakan rumus berikut:

$$
\mathrm{TCR}=\frac{\mathrm{Rs}}{\mathrm{n}} \quad \mathrm{x} 100 \%
$$

Keterangan :

TCR=Tingkat Capaian Responden

Rs =Rata-rata skor jawaban responden (rerata)

$\mathrm{N}$ =Nilai skor jawaban

Arikunto (2006) menyatakan bahwa kriteria nilai tingkat capaian responden TCR dapat diklasifikasikan sebagai berikut : 
Persentase pencapaian kriteria

$\begin{array}{ll}80 \%-100 \% & \text { : sangat baik } \\ 60 \%-80 \% & \text { : baik } \\ 40 \%-60 \% & \text { : cukup baik } \\ 20 \%-40 \% & \text { : kurang baik } \\ <20 \% & \text { : tidak baik }\end{array}$

Uji Asumsi Klasik juga tidak perlu di lakukan untuk analisi regresi linier yang bertujuan untuk menghitung nilai pada variable tertentu.Misalnya nilai return saham dihitung dengan market model ,atau market adjusted model.Perhitungan nilai return yang diaharapkan di lakukan dengan persamaan regresi ,tetapi tidak perlu di uji asumsi klasik.

Analisa dapat dilakukan tergantung pada data yang ada .Sebagai contoh, di lakukan analisis terhadap semua uji asumsi klasik,lalu di lihat mana yang tidak memenuhi persyaratan, di lakukan pengujian pada uji yang lain, terdapat 3 pengujian asumsi klasik sebagai berikut :

1. Uji Normalitas adalah uji yang digunakan untuk melihat apakah dalam regresi, variabel dependen dan variabel independen atau keduanya mempunyai distribusi normal atau tidak..Alat uji yang di gunakan adalah uji onesample Kolmogorov test dengan pedoman pengambil keputusan berikut :

- jika nilai sig atau probabilitas < dari a $=0,05$ maka sebaran data tidak berdistribusi normal.

- Jika nilai sig atau probabilitas > dari a =0,05 maka sebaran data berdistribusi normal

2. Uji Heteroskedastisitas menurut Ghozali (2008) dalam (Muliani Singgih \& Rangga Bawono, 2010), uji heteroskedastisitas bertujuan untuk menguji apakah dalam model regresi terjadi ketidaksamaan varians dari residual satu pengamatan ke pengamatan yang lain.Jika varians dari residual satu panagamtan ke pengamatan lain tetap ,maka di sebut heteroskedastisitas, dan jika berbeda di sebut heteroskedastisitas .Untuk mendekteksi adanya heteroskedastisitas dapat menggunakan Uji Glejser.Dalam uji ini apabila signifikansi >0,05 atau kesalahan menolak data maka tidak terdapat gejala heteroskedastisitas, model yang baik adalah tidak terjadi heteroskedastisitas (Ghozali,2005).

3.Uji Multikolonieritas Sebelum memakai analisis dengan menggunakan regresi linier berganda.Terlebih dahulu dilakukan uji Multikolonieritas yaitu uji hubungan sesamavariabel independen.Uji multikolonieritas ini berguna untuk menghindari supaya jangan ada di anatara variabel independen yang berkorelasi sesamanya ,maka terlebih dahulu harus dilihat hubungan dari masing-masing variabel dengan melihat nilai VIF.Menurut Ghozali (2008), untuk mendeteksi ada atau tidaknya multikoloniertas dapat dilihat dari nilai tolerance dan Variance Inflation Faktor (VIF).Nilai toleranceyang umum di pakai adalah $>0,10$ atau sama dengan nilai $\mathrm{VIF}<10$ yang menandakan tidak terjadinya multikolonieritas.

Uji Regresi Linear Berganda adalah suatu teknik statistik yang digunakan untuk mengetahui seberapa besar pengaruh beberapa variabel bebas terhadap variabel terikat. Tujuan menggunakan analisis berganda dalam penelitian ini 
adalah untuk mengetahuiPengaruh Kepemimpinan Transformasional dan Kepuasan Kerja terhadapOrganizational Citizenship Behaviourdengan persamaan sebagai berikut:

$\mathrm{Y}=\mathrm{a}+\mathrm{b} 1 \mathrm{X}_{1}+\mathrm{b} 2 \mathrm{X}_{2}+\mathrm{e}$

Dimana:

Y= Organizational Citizenship Behaviour

$\mathrm{a}=$ Konstanta

b1 $=$ Koefisien regresi Kepemimpinan Transformasional

b2 = Koefisien regresi Kepuasan Kerja

$\mathrm{X}_{1}=$ Kepemimpinan Transformasional

$\mathrm{X}_{2}=$ Kepuasan Kerja

\section{Uji Hipotesis}

1. Uji Statistik $\mathbf{F}$ di gunakan untuk mengetahui semua variabel bebas secara bersama-sama terhadap nilai variabel terikat .pengujian ini dilakukan dengan membandingkan nilai $\mathrm{F}$ hitung dengan $\mathrm{F}$ table.Jika $\mathrm{F}$ hitung $>\mathrm{F}$ table ,maka Ho di tolak dan Ha di terima.Artinya variabel bebas secara bersama -sama mempunyai pengaruh terhadap variabel terikat.Dan jika $\mathrm{F}$ hitung $<\mathrm{F}$ table maka variabel bebas secara bersama-sama tidak mempunyai pengaruh pada table terikat .F table di cari dari tingkat kepercayaan (a)dan derjat kebebasan (k,n-k-1).Pengujian signifikasi koefesien regresi dengan uji F.Pengujian ini bermaksud untuk mengetahui apakah kedua variabel tersebut secara bersama-sama mempengaruhi minat konsumen menabung .Pengujian ini akan di lakukan dengan menguji $F$ pada tingkat kepercayaan 95\%(a =0,05) dan derjat kebebasan tertentu ,sehingga dengan penguji ini $\mathrm{F}$ ini akan di ketahui hubungan variabel independent (X) dengan variabel dependent ( Y ).

2. Uji Hipotesis (Uji T) Koefesien regresi bertujuan untuk mengetahui apakah variabel bebas yang terhadap dalam persamaan secara individu berpengruh terhadap variabel terikat.Carany adalah dengan melakukan pengujian hipotesis terhadap koefesien regresi semua dari hasil dari hipotesis ini ,pada tingkat kepercayaan dan derajat kebebasan tertentu akan di peroleh hasil $\mathrm{t}$ hitung dan $\mathrm{t}$ table .

Menurut Sugiyono (2007) dasar pengambilan keputusan untuk pengujian hipotesis adalah :

a.Jika nilai signifikan $<(0,05)$ maka terdapat pengaruh yang signifikan atau berarti dari variabel bebas terhadap variabel terikat.

b.Jika nilai signifikan $>(0,05)$ maka tidak terdapat pengaruh yang tidak signifikan atau tidak berarti dari variabel bebas terhadap variabel terikat.

3.Koefisien Determinan $\left(\mathrm{R}^{2}\right)$ untuk mengetahui tingkat ketepatan paling baik dalam analisis regresi, dimana hal yang ditunjukan oleh besarnya koefisien determinasi $\left(\mathrm{R}^{2}\right)$ antara nol (0) dan (1). Koefisien determinasi nol variable independent sama sekali tidak berpengaruh terhadap variable dependen. Apabila koefisien determinasi semakin mendekati satu, maka dapat dikatakan bahwa variable independen berpengaruh terhadap variabel dependen. Koefisien determinasi dipergunakan untuk mengetahui presentase perubahan variabel terikat (Y) yang disebabkan oleh variabel bebas $(\mathrm{X})$. 


\section{HASIL PENELITIAN DAN PEMBAHASAN \\ Profil Responden}

Untuk memperoleh data dalam pengujian ini, penulis membagikan kuesioner kepada 42 responden. Jumlah sampel kuesioner tersebut merupakan jumlah dari keseluruhan dari populasi yang juga berjumlah 42 orang yang merupakan seluruh karyawan Pln Rayon Belanti. Peneliti merasa sangat bersyukur, dari semua kuesioner yang peneliti sebarkan sebanyak 42 sampel, seluruhnya dapat dikembalikan kepada peneliti dengan utuh dan lengkap.Berikut ini adalah pengelompokan profil responden yang dibagi berdasarkan jenis kelamin, usia, pendidikan, dan lama bekerja.

Tabel 2

distribusi responden

\begin{tabular}{llcc}
\hline Responden & Keterangan & Frekuensi & Percent \\
\hline Jenis kelamin & Laki-laki & 30 & 71.4 \\
& Perempuan & 12 & 28.6 \\
\hline Umur & 18-25 tahun & 9 & 21.4 \\
& 26-35 tahun & 15 & 35.7 \\
& 36-46 tahun & 12 & 28.6 \\
pendidikan & Lebih dari 46 tahun & 6 & 14.3 \\
& Sma/sederjat & 12 & 28.6 \\
& Diploma & 13 & 31.0 \\
Golongan & Sarjana (S1) & 17 & 40.5 \\
& 2 & 22 & 52.4 \\
& 3 & 16 & 38.1 \\
& 4 & 4 & 9.5 \\
\hline
\end{tabular}

Dari data pada tabel di atas diketahui bahwa total penelitian ini berjumlah 42 responden,berdasarkan jenis kelamin laki-laki banyak dari pada perempuan dengan jumlah 30 orang dengan pesentase $71,4 \%$. Berdasarkan usia kebanyakkan responden yang bekerja di perusahan tersebut berusia 26-35 tahun jumlah 15 orang persentase $35,7 \%$.Berdasarkan pendidikan, karywan yang bekerja di perusahaan tersebut banyak dari sarjana dengan jumlah 17 orang persentase 40,5\%.Berdasarkan golongan banyak dari golongan 2 jumlah 22 orang $52,4 \%$.

\section{Uji Regresi Linear Berganda}

Analisis regresi berganda digunakan untuk mengetahui hubungan atau pengaruh antara dua atau lebih variabel bebas $(\mathrm{X})$ dengan satu variabel tergantung (Y) yang ditampilkan dalam bentuk persamaan regresi. Analisis ini bertujuan untuk memprediksikan nilai dari variabel tergantung apabila nilai dari variabel bebas mengalami kenaikan atau penurunan dan untuk mengetahui arah hubungan. Hasil olah data untuk regresi linear berganda untuk semua variabel dapat dilihat pada tabel 3 . 
Tabel 3

Hasil Uji Linear Berganda

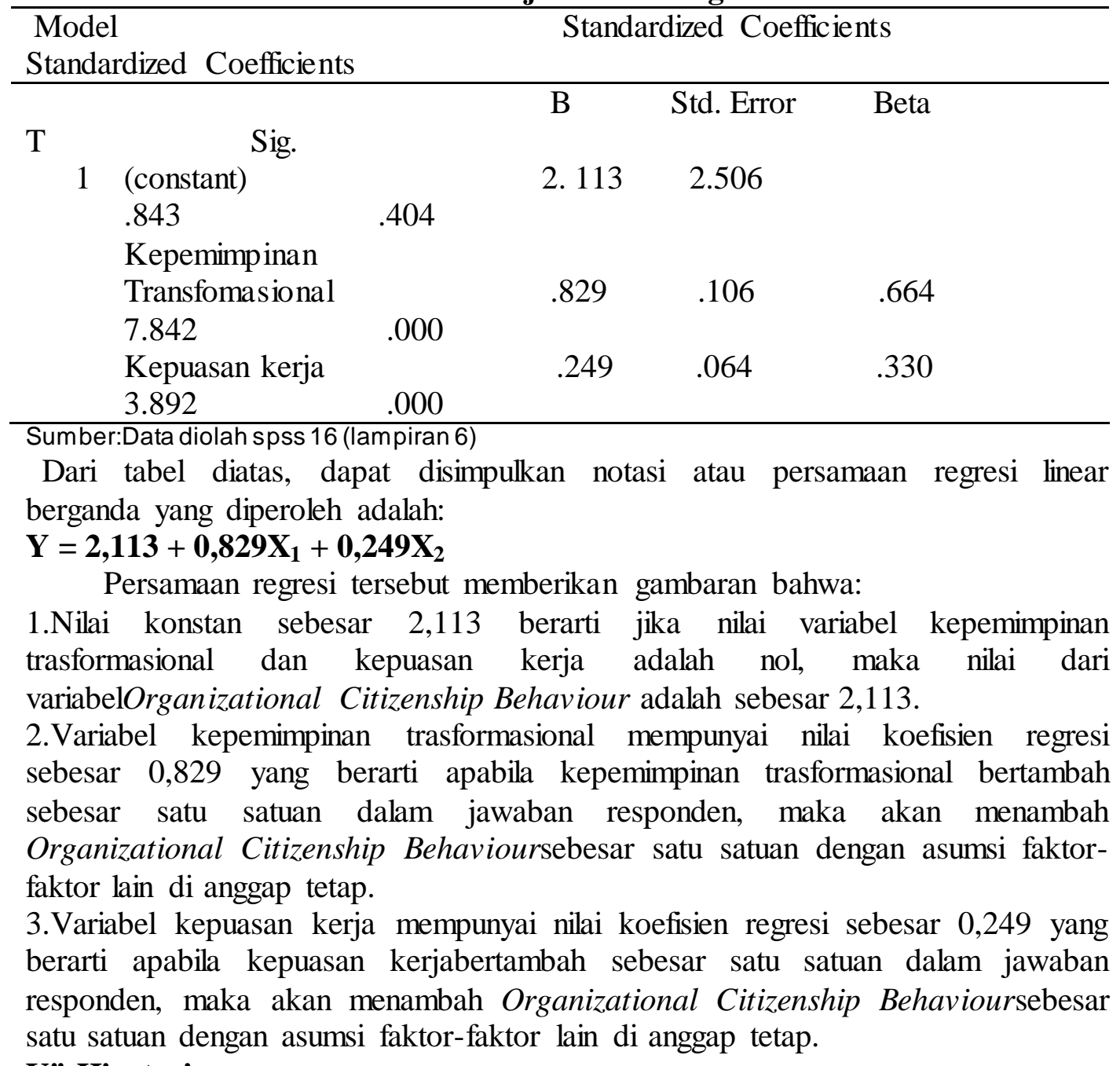

\section{Uji Hipotesis}

1. Uji Staatistik F ,Pengujian ini dilakukan untuk mengetahui apakah semua variabel independen secara bersama-sama (simultan) dapat mempengaruhi terhadap variabel dependen dari suatu persamaan regresi yang di dasarkan pada nilai probabilitas $a=0,05$.

\section{Tabel 4}

\section{uji F (Simultan)}

\begin{tabular}{lcccc}
\hline $\begin{array}{l}\text { Model } \\
\text { Sig. }\end{array}$ & Sum of squares & DF & mean square & F \\
\hline $\begin{array}{l}1 \text { regression } \\
.000^{\mathrm{a}}\end{array}$ & 1404.103 & 2 & 702.052 & 205.803 \\
$\quad$ Residual & 133.040 & 39 & 3.411 & \\
$\quad$ Total & 1537.143 & 41 & & \\
\hline
\end{tabular}

Sumber : Data diolah SPSS 16 ( Lampiran 7)

Nilai F hitung sebesar 205,803 yang signifikan $0.000^{\mathrm{a}}$. Karena sig $<0,05$ ini berarti rumusan hipotesis yang menyatakan bahwa kepemimpinan 
trasformasional dan kepuasan kerja berpengaruh secara simultan terhadapOrganizational Citizenship Behaviour.

2. Uji Hipotesis $\mathbf{T}$ untuk mengetahui pengaruh variabel indipenden secara parsial terhadap variabel dipenden dengan membandingkan nilai $t$ signifikan dengan taraf nyata $95 \%$. Penelitian ini menggunakan probabilitas taraf nyata 95\% atau $\alpha=0.05$ sehingga dapat diketahui pengaruh variabel bebas secara individu dengan kriteria jika $\mathrm{t}$ signifikan $<\alpha=0.05$ maka dapat dikatakan variabel bebas berpengaruh signifikan terhadap variabel terikat. Jika $t$ signifikan $>\alpha=0,05$ maka dapat dikatakan variabel bebas tidak berpengaruh signifikan terhadap variabel terikat dan membandingkan probabilitas pada taraf nyata 95\% dari koefisien parsial (r) sehingga dapat diketahui pengaruh variabel bebas secara individu dengan menggunakan kriteria uji hipótesis dengan uji $\mathrm{t}$ sebagai berikut:

- Thitung <ttabel $(0,05)$, maka Ho diterima sehingga Ha ditolak.

- Thitung >ttabel $(0,05)$, maka Ho ditolak sehingga Ha diterima.

Hasil pengujian hipotesis secara parsial dapat dilihat dalam tabel dibawah ini:

\section{Tabel 5}

Hasil Uji T

\begin{tabular}{lrrrr}
\hline Model & Unstandardized & Coefficients & Standardized Coefficients & \\
\hline Sig. & $\mathrm{B}$ & std.Eror & beta & $\mathrm{T}$ \\
$\begin{array}{l}1 \text { (constant) } \\
.404\end{array}$ & 2.113 & 2.506 & & .843 \\
$\quad$ Totalkt & .829 & .106 & .664 & 7.842 \\
.000 & & & & \\
$\quad$ Totalkp & .249 & .064 & .330 & 3.892 \\
.000 & & & & \\
\hline
\end{tabular}

Sumber : Data diolah SPSS 16 ( Lampiran 7)

Dari tabel dapat disimpulkan sebagai berikut :

Jika tingkat signifikannya $\leq$ dari 0,05 maka hipotesis di tolak(koefesien regresi tidak signifikan) sebaliknya jika nilai signifikan $\geq 0,05$ maka hipotesis diterima (koefesien regresi signifikan ).Dari tabel di atas bahwa variabel kepemimpinan transformasional dan kepuasan kerja berpengaruh signifikan terhadap OCB karena kecil dari 0,05 yaitu 000 .

1. Uji Parsial variabel kepemimpianan trasformasionalterhadap variable Organizational Citizenship Behaviour dari hasil pengujian yang dilakukan dan nampak pada Tabel 4.18 diperoleh thitung $(7,842)>t$ tabel $(2,02108)$, Maka Ho diterima sehingga $\mathrm{Ha}$ ditolak, hal ini menunjukan adanya positif dan signifikan pengaruh variable kepemimpianan trasformasionalterhadap variabel Organizational Citizenship Behaviouradalah signifikan.

2. Uji Parsial variabel kepuasan kerjaterhadap variable Organizational Citizenship Behaviour dari hasil pengujian yang dilakukan dan nampak pada Tabel 4.18 diperoleh thitung $(3,892)>t$ tabel (2,02108), Maka Ho diterima sehingga Ha ditolak, hal ini menunjukan adanya positif dan signifikan pengaruh variable kepuasan kerja terhadap variabel Organizational Citizenship Behaviouradalah signifikan 
3.Uji Koefisien Determinasi ( $\left.\mathrm{R}^{2}\right)$

Hasil uji Koefisien Determinasi ( $\mathrm{R}^{2}$ ) dalam penelitian ini dapat dilihat pada tabel berikut

Tabel 6

Uji Koefisien Determinasi ( $\left.\mathbf{R}^{2}\right)$

\begin{tabular}{llccc}
\hline Model & $\mathrm{R}$ & $\mathrm{R}$ Square & Adjustied R Square & std. eror of the estimate \\
\hline 1 & .956 & .931 & .909 & 1.84696 \\
\hline
\end{tabular}

Sumber : Data diolah SPSS 16 ( Lampiran 7)

Pada tabel di atas di peroleh nilai adjusted $\mathrm{R}$ square adalah 0,909 artinya sebesar 90,9\% variabel kepemimpinan transformasional dan kepuasan kerja mampu menjelaskanOrganizational Citizenship Behaviourdan sisanya 18,2\% dipengaruhi oleh faktor lain yang tidak diteliti seperti kinerja, disiplin,teliti,cerdas.

Pembahasan

1.Pengaruh Kepemimpinan Transformasional Terhadap Organizational Citizenship Behaviour

Kepemimpinan transformasional berpengaruh positif dan signifikan terhadapOrganizational Citizenship Behaviourhal ini dilihat dari nilai thitung $(7,842)>t$ tabel (2,02108). Artinya adanya hubungan antara kepemimpinan transformasional dengan peningkatan Organizational Citizenship Behaviour di PT. PLN Rayon Belanti, apabila kepemimpinan trasformasional baik maka akan meningkatkanOrganizational Citizenship Behaviour, hal ini dapat dilihat dari tingkat pekerjaan karyawan PT. PLN Belanti yang loyal dan mau mengerjakan pekerjaan dengan tepat waktu misalkan adanya transformator (trafo) rusak maka karyawan langsung mengtahui melalui multi meter sehingga kayawan langsung memperbaiki trafo yang rusak atas instruksi dari pemimpin mereka, sehingga H1 diterima.

Penelitian ini mendukung teori yang dikembangkan olehMenurut Rahmi (2003) yang meneliti tentang pengaruh kepemimpinan transformasional terhadap organizational citizenship behaviour, menunjukkan bahwa kepemimpinan transformasional berpengaruh positif dan signifikan terhadap organizational citizenship behavior.Penelitian ini sejalan dengan penelitian yang dilakukan oleh Adhityo Prabowo (2014) dengan judul analisis pengaruh kepemimpinan trasformasional dan kepuasan kerja terhadap Organizational Citizenship Behaviourdengan komitmen organisasi sebagai variabel intervening.

2.Pengaruh Kepuasan kerja Terhadap Organizational Citizenship Behaviour

Kepuasan kerja berpengaruh positif dan signifikan terhadapOrganizational Citizenship Behaviourhal ini dilihat dari nilai thitung $(3,892)>t$ tabel (2,02108). Artinya adanya hubungan antara kepuasan kerja dengan peningkatan Organizational Citizenship Behaviour di PT. PLN Rayon Belanti, apabila kepuasan kerja baik maka akan meningkatkan Organizational Citizenship Behaviour, hal ini dapat dilihat dari tingkat pekerjaan karyawan PT. PLN Belanti yang loyal dan cepat tanggap dalam menangani masalah yang terjadi di lapangan mengenai kerusakan maupun perbaikan listrik. Hal ini mencerminkan bahwa karyawan PT. PLN Rayon Belanti mempunyai kepuasan kerja disana dan mau bersikap loyal dan sukarela dalam melakukan pekerjaannya, sehingga H2 diterima. 
Penelitian ini mendukung teori yang dikembangkan olehKreitner dan Kinicki (2005), Kepuasan kerja merupakan hal yang bersifat individual. Setiap individu mempunyai tingkat kepuasan yang berbeda-beda.Penelitian ini sejalan dengan penelitian yang dilakukan oleh Franciscus Jefri Otmo (2004) dengan judul pengaruh karakteristik pekerjaan dan kepuasan kerja terhadap Organizational Citizenship Behaviourpada karyawan PT. Menara Agung,menunjukkan bahwa kepuasan kerja berpengaruh positif dan signifikan terhadap organizational citizenship behavior.

\section{SIMPULAN}

Berdasarkan uraian dan hasil analisis pada bab - bab sebelumnya mengenai Mengetahui Pengaruh kepemimpinan trasformasional dan kepauasan kerja terhadap organizational citizenship behavior pada PT. PLN Rayan Belanti. dapat diambil kesimpulan dan saran sebagai berikut:

1.Kepemimpinan transformasional berpengaruh positif dan signifikan terhadapOrganizational Citizenship Behaviour.

2.Kepuasan kerja berpengaruh positif dan signifikan terhadapOrganizational Citizenship Behaviour.

\section{UCAPAN TERIMA KASIH}

Terima kasih kepada ketua STIE'KBP',Ketua Program Studi,Dosen Pembimbing Skripsi,Dosen Pembimbing Akademik,dan atau lembaga/institusi yang telah membantu dalam pelaksanaan penelitian dan penulisan karya ilmiah serta lembaga lain yang berkontribusi terhadap penulis.

\section{DAFTAR PUSTAKA}

Baihaqi, M. F. (2010). Pengaruh Gaya Kepemimpinan terhadap Kepuasan Kerja dan Kinerja dengan Komitmen Organisasi sebagai Variabel Intervening, 1146.

Hilda, N. (2014). Strategi Inovasi Layanan dalam Meningkatkan Kualitas Pelayanan di Kantor Pertanahan Kota Surabaya II. Kebijakan Dan Manajemen Publik, 2(1), 1-10. Retrieved from http//journal.unair.ac.id/download-fullpapers-kmpdd76ece88cfull.pdf

Junaidi, R., \& Susanti, F. (2019). Pengaruh Gaya Kepemimpinan Dan Budaya Organisasi Terhadap Kinerja Pegawai Pada UPTD Baltekkomdik Dinas Pendidikan Provinsi Sumatera Barat. https//doi.org/10.31227/osf.io/bzq75

Kaihatu, T. S., \& Rini, W. A. (2007). Kepemimpinan Transformasional dan Pengaruhnya Terhadap Kepuasan atas Kualitas Kehidupan Kerja Komitmen Organisasi dan Perilaku Ekstra Peran: Studi pada Guru-Guru SMU di Kota Surabaya. Jurnal Manajemen Dan Kewirausahaan, 9, pp.49-61. Retrieved from http://puslit2.petra.ac.id/ejournal/index.php/man/article/view/16635 
Lubis, A. Y. O., \& Susanti, F. (2019). Pengaruh Gaya Kepemimpinan Dan Kompensasi Terhadap Prestasi Kerja Karyawan (Studi pada PT Japfa Comfeed Indonesia (JCI) Tbk Devisi Fam 1. https://doi.org/10.31227/osf.io/7tbrg

Mayliza, R. (2019). Pengaruh Gaya Kepemimpinan Dan Disiplin Kerja Terhadap Kinerja Karyawan Dengan Motivasi Kerja Sebagai Variabel Intervening Pada PT. Semen Padang. https://doi.org/10.17605/OSF.IO/FYPQ9.

Mayliza, R. (2019). Pengaruh Gaya Kepemimpinan Dan Disiplin Kerja Terhadap Kinerja Pegawai, Dengan Motivasi Kerja Sebagai Variabel Intervening (Studi Pada Dinas Pendidikan Kabupaten Tanah Datar). https://doi.org/10.17605/OSF.IO/JGPDN

Mayliza, R. (2019). Pengaruh Kepuasan Kerja Dan Loyalitas Kerja Terhadap Organizational Citizenship Behavior (OCB) Pada Pegawai BPKPAD Di Madina. https://doi.org/10.17605/OSF.IO/5PVWB

Muliani Singgih, E., \& Rangga Bawono, I. (2010). Pengaruh Independensi, Pengalaman, Due Professiona Care dan Akuntabilitas Terhadap Kualitas Audit. Journal of Chemical Information and Modeling, 53(9), 1689-1699. https://doi.org/10.1017/CBO9781107415324.004

Psikologi, F., Islam, U., \& Syarif, N. (2017). Tranformasional Dan Demografi Terhadap Organizational Citizenship Behavior (OCB).

Rahmi, B. M. (2013). Pengaruh Kepemimpinan Transformasional terhadap Organizational Citizenship Behavior dan Kepuasan Kerja (Studi pada Guru Tetap SMA Negeri di Kabupaten Lombok Timur), 330-350.

Susanto, Y. K. (2011). Karakteristik Saham, Kebijakan Dividen, Karakteristik perusahaan, Risiko Sistematik, Set Peluang Investasi dan Kebijakan Hutang. Jurnal Bisnis Dan Akuntansi, 13(3), 195-210.

Syadeli, M. (2013). Struktur Kepemilikan, Profitabilitas Dan Ukuran Perusahaan Terhadap Kebijakan Hutang Perusahaan Pemanufakturan Di Bursa Efek Indonesia. Jurnal Manajemen Dan Akuntansi, 2(2), 79-94.

Tunjungsari, P. (2011). Pengaruh Stress Kerja Terhadap Kepuasan Kerja Karyawan Pada Kantor Pusat PT. Pos Indonesia (Persero) Bandung. Universitas Komputer Indonesia, 1(1), 1-14.

Yunas, N., \& Dewi, A. S. (2018). Pengaruh Pengendalian Internal Dan Gaya Kepemimpinan Terhadap Kinerja Karyawan Pada PT. Garuda Indonesia (Persero) Tbk Branch Office Padang. https://doi.org/10.31219/osf.io/3a2u6 